\title{
Comparison of the application methods of impression materials for customized posts
}

\author{
Analiza porównawcza metod aplikacji masy wyciskowej pod indywidualne \\ wkłady koronowo-korzeniowe
}

\section{Pawel Fiwek, Martyna Miklaszewska, Aleksandra Tobojka, Izabela Maciejewska}

Katedra i Zakład Protetyki Stomatologicznej, Gdański Uniwersytet Medyczny

Department of Prosthodontics, Medical University of Gdansk

Head: dr n. med. Iwona Ordyniec-Kwaśnica

KEY WORDS:

impression, individual post, 3D-Tool analysis

\section{Summary}

A dental post is a permanent restoration fixed permanently in the patient's tooth. The post consists of radicular and coronal parts. The former is responsible for the retention of the entire restoration, while the latter one restores lost tissues of the tooth crown. Many types of dental posts are used. However, the individual ones offer the most conservative preparation of a tooth canal, subsequently preserving the remaining tooth tissues. This directly increases the strength of the future restoration. Correct preparation of the individual post depends on the accuracy of the canal reproduction and the quality of the impression. The purpose of this study was to determine the best method of taking dental impressions for the most precise post preparation. A total of 162 impressions obtained by means of three methods were taken (54 teeth each): the PISTOL method, where the impression materialwas injected into the root canal using a standard impression pistol, the LENTULO method, where the material was injected into the root canal using a standard impression pistol and was subsequently condensed with a Lentulo needle, the NEEDLE method, where an injection needle was inserted into the
HASŁA INDEKSOWE:

wycisk, indywidualne wkłady koronowo-korzeniowe, analiza 3D-Tool

\section{Streszczenie}

Wkłady koronowo-korzeniowe (wkłady $k$-k) należa do stałych uzupetnień protetycznych, które mocowane sa trwale na zębach wtasnych pacjenta. Wkłady k-k złożone sa z części korzeniowej, która odpowiada za retencje uzupetnienia oraz części koronowej, odtwarzającej część utraconych tkanek korony zęba. Obecnie stosowanych jest wiele rodzajów wktadów $k$-k, jednak zastosowanie wkładów indywidualnych, poprzez minimalna preparacje kanatu, pozwala na zachowanie największej ilości tkanek zęba, co bezpośrednio skutkuje większa wytrzymatościa przyszlej odbudowy. Poprawne wykonanie indywidualnego wktadu k-k zależy od doktadności opracowania kanału oraz jakości pobranego wycisku. Cel pracy stanowito określenie metody wykonywania wycisku, która pozwala na wykonanie jak najbardziej precyzyjnego wktadu. 162 wyciski pobierano 3 metodami (54 każda metoda): PISTOLET - mase wyciskowa wstrzykiwano do kanatu korzeniowego za pomoca standardowego pistoletu; LENTULO - mase wstrzykiwano przy użyciu pistoletu $i$ kondensowano igta Lentulo; IGEA - do kanału wprowadzano igte iniekcyjna, wzdtuż której pistoletem wstrzykiwano masę. Wy- 
canal, followed by an injection of the impression material with a standard impression pistol. After setting, the impressions were analysed clinically, independently by two dentists, followed by an independent, digital analysis. The results showed that the best method to obtain the precise root canal impression in both single- and multi-canal teeth is the LENTULO method, while the worst is the PISTOL method.

\section{Introduction}

Dental posts are permanent restorations fixed in the patient's tooth. It is a retention element for the prosthetic crown after an extensive destruction of the physiological tooth crown. ${ }^{1-3}$ Currently, two types of post are used: standard and customized ones. The standard posts are pre-made elements made of metal, ceramic or composite which is fibrereinforced (FRP). 1,2,4 The custom-made posts are prepared individually for the specific tooth. Numerous references indicate the advantage of such posts over the standard ones. ${ }^{5-8}$ Due to the minimal root canal preparation, which usually involves partial removal of the root filling material with unavoidable marginal extension into root dentine, maximum amount of dental tissue is maintained. Perfect adhesion of the post surface to the inner surface of the root canal significantly improves the resistance of the future prosthetic restoration. ${ }^{9}$ The ideal preparation of the individual post depends on the accuracy of the canal preparation and its recording by means of an impression, which directly influences the proper adhesion of the future dental restoration and the maximum tightness of its seal. , $^{1,4,6}$

While the process of post preparation is well known and described in detail in the available literature, there are few reports detailing the application and/or condensation ciski poddano standardowej analizie klinicznej niezależnie przez dwóch lekarzy oraz analizie cyfrowej. Analizy wykazaty, że najlepsza metode do wykonania doktadnego wycisku, zarówno w zębach jedno- jak $i$ wielokanałowych jest metoda LENTULO, a najgorsza metoda PISTOLET.

\section{Wstęp}

Wkłady koronowo-korzeniowe są uzupełnieniem protetycznym mocowanym na stałe na zębach własnych pacjenta. Stanowią one element retencyjny dla koron protetycznych w przypadku rozległego zniszczenia tkanek korony zęba. ${ }^{1-3}$ Obecnie stosowane są dwa rodzaje wkładów: standardowe oraz indywidualne. Wkłady standardowe są gotowymi elementami, wykonanymi z metalu, ceramiki lub kompozytów wzmocnionych włóknami (FRP), 1,2,4 natomiast wkłady indywidualne są uzupełnieniem modelowanym indywidualnie dla każdego zęba. Liczne piśmiennictwo wskazuje przewagę wkładów indywidualnych nad standardowymi. ${ }^{5-8}$ Poprzez minimalną preparację, polegającą na usunięciu części materiału wypełniającego kanał oraz jego niezbędnym poszerzeniu, umożliwiają one zachowanie maksymalnej ilości tkanek zęba. Idealne przyleganie powierzchni wkładu do wnętrza kanału korzeniowego znacząco poprawia wytrzymałość przyszłej odbudowy protetycznej. ${ }^{9}$ Poprawne wykonanie indywidualnego wkładu k-k zależy od dokładności opracowania kanału oraz zobrazowania wnętrza kanału korzeniowego za pomocą wycisku, co bezpośrednio przekłada się na właściwe przyleganie przyszłej odbudowy i jej maksymalną szczelność. ${ }^{1,3,4,6}$

$\mathrm{O}$ ile sam proces wykonania wkładu jest dobrze poznany i szczegółowo opisany 
of light impression material in the root canal, which precisely shows the anatomical conditions in the prepared canal. Available publications only indicate the use of the spiral root filler but do not specify the order of the procedure. ${ }^{9,10}$ Moreover, many years of clinical experience indicate that the most commonly used impression method, with the use of the standard application pistol with deep placement of intra-oral tip, necessitates the repetition of the procedure, especially in the narrow root canals. Hence, the valid need to present and discuss guidelines defining the principles of material application into the prepared root canal, which will allow obtaining the perfect impression.

The aim of the study was to compare three methods of taking the impressions of the prepared root canal using the modified methods of impression material application, which would allow defining the optimal method for this dental procedure.

\section{Material and methods}

The 162 impressions taken from human permanent teeth were evaluated. The teeth were removed for medical reasons at the Oral Surgery Department, Medical University of Gdańsk, after obtaining patients' written consent. All the patients were adults, both male and female. The study was approved by the Independent Bioethics Committee of the Medical University of Gdańsk (NKBBN/300/2013)

The impressions were taken with three methods (54 teeth for each one) with 78 and 84 impressions taken in the single and multi-canal teeth, respectively. The teeth were labelled for further analysis after being clinically accepted for a post reconstruction (26 single-rooted teeth and 28 multi-rooted teeth). The incisors, canines and premolars were included in the group of the single-rooted teeth (with the exception of w dostępnej literaturze, to brakuje w niej doniesień, w których w sposób szczegółowy opisano proces aplikacji i/lub kondensacji rzadkiej masy wyciskowej w kanale korzeniowym zapewniający jak najbardziej precyzyjne zobrazowanie warunków anatomicznych w opracowanym kanale. Dostępne publikacje wskazują jedynie na zastosowanie igły Lentulo, ale nie precyzują kolejności wykonania procedury. ${ }^{9,10}$ Ponadto, wieloletnie doświadczenia kliniczne wskazują, że najczęściej stosowana metoda wyciskowa, z użyciem standardowego pistoletu służącego do aplikacji rzadkiej masy nawet przy głębokim umiejscowieniu końcówki wewnątrzkanałowej, często wymusza konieczność powtórzenia wycisku, szczególnie w przypadku wąskich kanałów korzeniowych. Stąd, potrzeba przedstawienia i omówienia wytycznych określających zasady aplikowania masy do wnętrza kanału, które pozwolą na otrzymanie idealnego wycisku wydaje się być wciąż aktualna.

Celem pracy było porównanie 3 metod pobierania wycisków wnętrza kanału korzeniowego $\mathrm{z}$ zastosowaniem zmodyfikowanej metody aplikacji wyciskowej, co w założeniu pozwoliłoby na zdefiniowanie metody optymalnej dla tej procedury stomatologicznej.

\section{Materiały i metody}

Jako materiał badawczy posłużyły 162 wyciski pobrane na naturalnych, ludzkich zębach stałych, które usunięto ze wskazań ogólnomedycznych w Poradni Chirurgii Stomatologicznej UCS w Gdańsku. Zęby pozyskano od pełnoletnich pacjentów (kobiet i mężczyzn) po uzyskaniu ich pisemnej zgody. Na badania uzyskano zgodę Niezależnej Komisji Bioetycznej przy Gdańskim Uniwersytecie Medycznym (NKBBN/300/2013).

Wyciski pobierano trzema metodami, po $54 \mathrm{w}$ każdej z metod. W zębach jednokanałowych zostało wykonanych 78 wycisków i 84 w zębach wielokanałowych. Do badań 
two-canal upper first premolars). The group of multi-rooted teeth included exclusively molars (11 upper and 17 lower ones).

\section{Tooth preparation}

After decay removal, all the canals were treated endodontically with the Mtwo ${ }^{\circledR}$ VDW rotary tools and with K-file up to ISO 35 width and filled with the AH-plus sealer (Dentsply) and gutta-percha cones. Next, the teeth were positioned in the appropriate silicone molds and covered with white, class II plaster forming a model. Subsequently, after models release, the teeth crowns were cut off, up to about $2 \mathrm{~mm}$ above the cemento-enamel junction. Preparation of the tooth chamber, root canal and the bearing surface followed the standard clinical procedure. Largo-Peeso drills (sizes 2 and 3, Dentsply Maillefer) were used for canal preparation. They were drilled to the length determined by the clinical indications for the tooth restoration with the post. The main consideration was to maintain an appropriate ratio of the root-to-crown part (minimum 1: 1). 3 to $5 \mathrm{~mm}$ of gutta-percha was left at the canal tip. Each model was labelled with the subsequent letter of the alphabet, and each tooth with a subsequent number (excluding " 0 "). Before taking the impression, the models were immersed in water at room temperature for 30 minutes to obtain isolation and simulate oral cavity conditions. Subsequently, the models were dried with paper towels and each tooth was dried with an air stream from a 3-in-1 syringe for about $5 \mathrm{~s}$. The root canals were dried with a paper point (ISO size 35). An additional metal rod was adjusted as a retention bar for a canal part of an impression.

The impressions were taken with the twolayer, one-time method using the polyvinyl siloxane additive Honigum material of both putty and light consistency (DMG, Germany). This material has the feature of "shear thinning", kwalifikowano zęby, które zgodnie z postępowaniem klinicznym mogły być przydatne do wykonania wkładu k-k (26 zębów jednokorzeniowych i 28 zębów wielokorzeniowych). Do grupy zębów jednokorzeniowych włączono zęby sieczne, kły i zęby przedtrzonowe (z wyłączeniem zębów dwukanałowych). Grupa zębów wielokorzeniowych objęła jedynie zęby trzonowe (11 górnych i 17 dolnych).

\section{Przygotowanie zęba}

Po uprzednim usunięciu tkanek próchnicowych, wszystkie kanały w zakwalifikowanych zębach przeleczono endodontycznie z użyciem narzędzi maszynowych Mtwo ${ }^{\circledR}$ firmy VDW oraz narzędzi typu K-file do szerokości ISO 35, a następnie wypełniono uszczelniaczem $\mathrm{AH}-$ plus (Dentsply) oraz ćwiekami gutaperkowymi. Kolejno, zęby umieszczano w odpowiednich silikonowych formach i zalewano białym gipsem modelowym klasy II. Po uwolnieniu modeli, odcinano korony zębów, do wysokości około $2 \mathrm{~mm}$ powyżej granicy szkliwno-cementowej. Opracowanie komory, powierzchni nośnej i kanałów korzeniowych przeprowadzano analogicznie do standardowego postępowania klinicznego. Do opracowania kanałów posłużono się wiertłami typu Largo - Peeso. (rozmiar 2 i 3, Dentsply Maillefer). Były one opracowane na długość określaną przez kliniczne wskazania do odbudowy zęba przy użyciu wkładu $\mathrm{k}-\mathrm{k}$, z uwzględnieniem zachowania odpowiedniej proporcji długości części korzeniowej wkładu do przyszłej korony (minimalnie 1:1). Przy wierzchołkach pozostawiano 3-5 mm gutaperki. Każdy model oznaczano kolejną literą alfabetu, a każdy ząb kolejną liczbą naturalną (z wyłączeniem liczby „0”). Przed pobraniem wycisku modele zanurzano w wodzie o temperaturze pokojowej na 30 minut aby uzyskać izolację oraz odtworzyć warunki zbliżone do panujących w jamie ustnej. Kolejno, modele osuszano ręcznikami papierowymi, a konkretny ząb poddawano działaniu strumienia powietrza $\mathrm{z}$ dmuchawki 
which allows obtaining low viscosity caused by high forces. This guarantees easier penetration of the material into the root canal. The putty was mixed manually and applied to a metal, rotating impression tray. The light material was applied directly to the root canal with the standard pistol and subsequently treated with the three methods: 1) The PISTOL method the light material was injected directly from the intra-oral tip of the pistol into the root canal at the deepest possible position. As the canal was filled, the tip was slowly withdrawn. 2) The LENTULO method - the light material was injected from the standard pistol with intra-oral tip directly into the root canal, and thereafter condensed with a Lentulo needle at $4000 \mathrm{rpm}$. for 5 seconds. 3) The NEEDLE method - a separate injection needle was placed in each canal (size 25G), then the light material was injected from the standard pistol with an intraoral tip along the inserted injection needle. The needle acted as a vent. The needle was slowly removed from the canal, while further pressing of the material continued. After application of the material, the previously prepared metal post was inserted into each canal followed by application of the putty. After setting, the impressions were released and appropriately labelled. The impressions were evaluated clinically and digitally. Two physicians participated in the clinical random/ random analysis.

Two scales were adopted for the analysis:

Scale I - the impression was evaluated for the presence of air bubbles and voids in the canal part of the impression. The presence of bubbles eliminated the impression from further procedure, while the lack of bubbles and material continuity categorized the impression as acceptable.

Scale II - the impression was evaluated in terms of suitability in accordance with the following score: unitu przez ok 5s. Kanały korzeniowe osuszano przy użyciu sączków papierowych (ISO rozmiar 35). Przed wyciskiem zostały również odpowiednio przygotowane i przymierzone metalowe ćwieki retencyjne. Wyciski wykonywano metodą dwuwarstwową, jednoczasową przy użyciu masy poliwinylosiloksanowej typu addycyjnego Honigum firmy DMG (Niemcy), o konsystencji gęstej (putty) oraz rzadkiej (light). Masa ta cechuje się zjawiskiem, ,shear thinnig", które polega na pozyskiwaniu niskiej lepkości pod wpływem działania dużej siły, co gwarantuje łatwiejsze wnikanie masy do wnętrza kanału. Masa typu putty była mieszana ręcznie i nakładana na metalową, obrotową łyżkę wyciskową. Masę rzadką aplikowano bezpośrednio na ząb z pistoletu z końcówką mieszającą wykorzystując trzy metody: 1) PISTOLET - masa rzadka była wstrzykiwana wprost z pistoletu zakończonego końcówką wewnątrzkanałową do światła kanału korzeniowego przy możliwie najgłębszym położeniu aplikatora we wnętrzu kanału. W miarę wypełniania kanału końcówka była wolno wycofywana, 2) LENTULO - masa rzadka była wstrzykiwana z pistoletu końcówką wewnątrzkanałową bezpośrednio do wnętrza kanału, po czym kondensowano ją za pomocą igły Lentulo z prędkością obrotową 4000 obr./ min. przez 5 sekund, 3) IGŁA - w każdym kanale umieszczano osobną igłę iniekcyjną (rozmiar 25G), kolejno wstrzykiwano masę rzadką z pistoletu końcówką wewnątrzkanałową wzdłuż igły, która pełniła rolę wentyla odpowietrzającego. Następnie igła była wolno usuwana $z$ kanału, przy dalszym, jednoczesnym wtłaczaniu masy. Po zaaplikowaniu masy, do każdego kanału wprowadzano przygotowany wcześniej metalowy ćwiek, po czym nakładano łyżkę z gęstą masą. Po stężeniu mas, wyciski uwalniano, opisywano rodzaj użytej metody wyciskowej i numer wycisku z oznaczeń modelu. Wyciski oceniano klinicznie oraz komputerowo. W analizie klinicznej brało udział niezależnie dwóch lekarzy metodą random/random. 
1 point - impression clinically unacceptable (the presence of air bubbles, longitudinal or transverse interruption of the impression material continuity on the root surface),

2 points-impression not perfect but clinically acceptable (blunt end of the apical part of the canal impression),

3 points - the perfect impression (preserved continuity of material on the whole surface of impression, smooth end of the apical part of the canal impression)

The scores coming independently from two dentists were averaged (in the multi-canal teeth, each canal was assessed separately). Statistical analysis was performed using the Fisher's exact test and the post-hoc analysis was performed. Statistical significance level was set at $\mathrm{p} \leq 0.05$. the.

To obtain the full objectivity of the analysis, an innovative digital evaluation method was designed. The impressions were scanned with the CAD/CAM Zirkon-Zahn S600 ARTI laboratory scanner giving the 3-D digital model. Next, the 3-D model was analysed using the Zirkon-Zahn Modellier software. The volume of the canal part of the impression was measured, assuming that the bigger volume of the material exerted the greater pressure, and thus was able to fill the root canal more tightly. This led to the more accurate reproduction of the root canal. In order to compare the canal images from the three different application methods, a common reference point was determined by overlapping the impressions scans coming from each method. Then, three superimposed scans were cut off, which produced three models with the same base, which were recorded in the "stl" format and exported to the 3D-Tool programme. It allowed assessing the volume of a given model. The results obtained in this way were subjected to statistical analysis using the Fisher's exact test. The statistical significance level was set at $\mathrm{p} \leq 0.05$.
Zastosowano dwie skale ocen:

I - badano obecność pęcherzy powietrza i pustych przestrzeni w części wycisku odwzorowującej wnętrze kanału. Obecność pęcherzy w masie wyciskowej eliminowała wycisk z wykorzystania go do wykonania wkładu k-k, brak pęcherzy i zachowana ciągłość masy pozwalała zaakceptować wycisk.

II - oceniano wycisk pod kątem przydatności zgodnie z następującą punktacją:

1 pkt - wycisk nieakceptowalny klinicznie (obecność pęcherzy powietrza, podłużne lub poprzeczne przerwanie masy wyciskowej na powierzchni korzeniowej wycisku)

2 pkt - wycisk niedokładny, lecz akceptowalny klinicznie (zakończenie dowierzchołkowej części korzeniowej wycisku tempo zakończone)

3 pkt - wycisk idealny (zachowana ciągłość masy wyciskowej na całej powierzchni wycisku, gładkie zakończenie dowierzchokowej części korzeniowej wycisku)

Wyniki punktacji uzyskane przez lekarzy dla danego wycisku sumowano i uśredniono (w zębach wielokanałowych każdy kanał oceniano osobno). Analizą statystyczną przeprowadzono z użyciem dokładnego testu Fishera, wykonano analizę post-hoc. We wszystkich obliczeniach za poziom istotności statystycznej przyjęto $\mathrm{p} \leq 0,05$.

W celu obiektywizacji oceny wycisków dla potrzeb doświadczenia stworzono obiektywną, nowatorską cyfrową metodę ewaluacji. Wyciski umieszczano w skanerze laboratoryjnym CAD/ CAM ZirkonZahn S600 ARTI, gdzie skanowano ich powierzchnie. Tak otrzymany model 3D analizowano przy użyciu oprogramowania Zirkon-Zahn - Modellier. Mierzono objętość masy wprowadzonej do kanału, zakładając, że większa jej ilość wywierając większą prężność jest w stanie szczelniej wypełnić kanał korzeniowy i zarazem dokładniej odwzorować obraz kanału korzeniowego. W celu oceny odwzorowania kanału z wykorzystaniem 
Table 1. Ratio (\%) of impressions with the largest volume in the single-canal group depending on the impression method (LENTULO, NEEDLE, PISTOL). The method which produced the most beneficial result is underlined

\begin{tabular}{|l|c||}
\hline \multicolumn{2}{|c|}{ Single-canal teeth } \\
\hline & $\begin{array}{c}\text { Ratio of impressions with the } \\
\text { largest volume }\end{array}$ \\
\hline LENTULO & $\mathbf{5 5 . 2 \%}$ \\
\hline NEEDLE & $20.7 \%$ \\
\hline PISTOL & $24.1 \%$ \\
\hline Total & $100 \%$ \\
\hline
\end{tabular}

\section{Results}

\section{The assessment of impressions following digital analysis}

- in the single canal group:

The digital analysis of the impressions showed that $55.2 \%$ of impressions with the largest volume, were taken with the LENTULO method. In the same group of the single canal teeth, the impressions taken with the NEEDLE method were $20.7 \%$, and the PISTOL method $24.1 \%$. The results coming from the group where the LENTULO method was used, were statistically significantly better compared to the PISTOL $(\mathrm{p}=0.0307)$ and the NEEDLE method. $(p=0.0140)($ Tab. 1$)$.

\section{- the results in the group of multicanal teeth:}

The digital method of evaluation of the impressions taken in the group of multicanal teeth showed that the largest number of impressions with the largest volume, i.e. the most clinically correct ones, were taken using the LENTULO method (42.9\%). In contrast, the NEEDLE and PISTOL methods allowed taking the best impressions in the $39.3 \%$ and $17.8 \%$ of cases, respectively (Tab. 2).
Tab le 2. Ratio (\%) of the impressions with the largest volume in the multi-canal group depending on the impression method (LENTULO, NEEDLE, PISTOL). The method which produced the most beneficial result is underlined

\begin{tabular}{|l|c|}
\hline \multicolumn{2}{|c|}{ Multi-canal teeth } \\
\hline & $\begin{array}{c}\text { Ratio of impressions with the } \\
\text { largest volume }\end{array}$ \\
\hline LENTULO & $\mathbf{4 2 . 9 \%}$ \\
\hline NEEDLE & $39.3 \%$ \\
\hline PISTOL & $17.8 \%$ \\
\hline Total & $100 \%$ \\
\hline
\end{tabular}

trzech metod aplikacji masy, określono wspólny punkt odniesienia poprzez nałożenie na siebie skanów wycisków otrzymanych każdą metodą. Następnie odcinano trzy nałożone skany w miejscu uszypułowania, co dawało trzy modele o jednakowej podstawie, które zapisywano w formacie ,stl” $i$ eksportowano do programu 3D-Tool. Pozwalał on na ocenę objętości danego modelu. Otrzymane w ten sposób wyniki poddano analizie statystycznej z użyciem dokładnego testu Fishera, przyjmując poziom istotności statystycznej $\mathrm{p} \leq 0,05$.

\section{Wyniki}

\section{Wyniki wykonania wycisków $z$ użyciem metody cyfrowej}

- wyniki uzyskane w grupie zębów jednokanatowych:

Metoda cyfrowa oceny wycisków wykazała, że najwięcej, 55,2\% wycisków z największą objętością masy, pobierano metodą LENTULO. W tej samej grupie zębów jednokanałowych, wycisków pobieranych metodą IGŁA było 20,7\%, a metodą PISTOLET $24,1 \%$. W grupie wycisków z największą zmierzoną objętością masy, wycisków pobieranych metodą LENTULO było istotnie statystycznie 
Ta b l e 3. Ratio (\%) of successful and unsuccessful impressions in the single-canal group depending on the method of impression taking (LENTULO, NEEDLE, PISTOL). Underlined was the method in which the most clinically beneficial result was obtained

\begin{tabular}{|l|c|c|c|c|c|c||}
\hline \multirow{2}{*}{$\begin{array}{c}\text { Number } \\
\text { of tested } \\
\text { impressions } 78\end{array}$} & \multicolumn{2}{|c|}{ LENTULO } & \multicolumn{2}{c|}{ NEEDLE } & \multicolumn{2}{c|}{ PISTOL } \\
\cline { 2 - 7 } & $\begin{array}{c}\text { impressions } \\
\text { number }\end{array}$ & $\begin{array}{c}\text { impressions } \\
\text { ratio }\end{array}$ & $\begin{array}{c}\text { impressions } \\
\text { number }\end{array}$ & $\begin{array}{c}\text { impressions } \\
\text { ratio }\end{array}$ & $\begin{array}{c}\text { impressions } \\
\text { ratio }\end{array}$ & $\begin{array}{c}\text { impressions } \\
\text { number }\end{array}$ \\
\hline $\begin{array}{l}\text { Successful } \\
\text { impression } \\
\text { no bubbles } \\
\text { or shreds }\end{array}$ & 21 & $\mathbf{8 0 . 8 \%}$ & 15 & $57.7 \%$ & 15 & $57.7 \%$ \\
\hline $\begin{array}{l}\text { Unsuccesssful } \\
\text { impression } \\
\text { with bubbles } \\
\text { and shreds }\end{array}$ & 5 & $19.2 \%$ & 11 & $42.3 \%$ & 11 & $42.3 \%$ \\
\hline
\end{tabular}

\section{The results obtained in the $0 / 1$ rating scale}

- the results from the single canal group:

In the group of impressions taken with the PISTOL method, there were $57.7 \%$ of successful and $42.3 \%$ of unsuccessful impressions. In the group of impressions taken with the LENTULO method, there were $80.8 \%$ of successful and $19.2 \%$ of unsuccessful impressions. In the group of impressions taken with the NEEDLE method were $57.7 \%$ of successful impressions and $42.3 \%$ of unsuccessful impressions. There were no statistically significant differences between the impressions from the single canal group due to the method of taking an impression (Tab. 3).

- the results in the group of multicanal teeth:

In the group of impressions taken in the multicanal teeth, the PISTOL method was successful in $17.6 \%$ of impressions and unsuccessful in $82.4 \%$ of impressions. In the group of impressions takenwith the LENTULO method both successful and unsuccessful impressions were $50.0 \%$ each, while in the group of impressions taken with the NEEDLE method there were $28.6 \%$ of successful and $71.4 \%$ of unsuccessful impressions. There was a statistically significant difference between impressions from the LENTULO group więcej w porównaniu do metody PISTOLET $(p=0,0307)$ i metody IGŁA $(p=0,0140)($ tab. 1$)$.

- wyniki uzyskane w grupie zębów wielokanałowych:

Metoda cyfrowa oceny wycisków wykonanych w grupie zębów wielokanałowych wykazała, że najwięcej wycisków z największą objętością tj. najbardziej poprawnych klinicznie, pobierano metodą LENTULO (42,9\%). Natomiast, metody IGŁA oraz PISTOLET pozwoliły na pobranie najlepszych wycisków odpowiednio w $39,3 \%$ oraz $17,8 \%$ przypadków (tab. 2 ).

\section{Wyniki uzyskane w $0 / 1$ skali ocen}

- wyniki uzyskane w grupie zębów jednokanałowych:

W grupie wycisków pobieranych metodą PISTOLET było 57,7\% wycisków udanych i 42,3\% wycisków nieudanych. W grupie wycisków pobieranych metodą LENTULO było $80,8 \%$ wycisków udanych i 19,2\% wycisków nieudanych. W grupie wycisków pobieranych metodą IGŁA było 57,7\% wycisków udanych i 42,3\% wycisków nieudanych. Nie stwierdzono istotnych statystycznie różnic ze względu na metodę pobierania wycisku w grupie zębów jednokanałowych (tab. 3). 
Ta b le 4. Ratio (\%) of successful and unsuccessful impressions in the multi-canal group depending on the method of impression taking (LENTULO, NEEDLE, PISTOL). Underlining was the method in which the most clinically beneficial result was obtained

\begin{tabular}{|l|c|c|c|c|c|c|}
\hline \multirow{2}{*}{$\begin{array}{c}\text { Number } \\
\text { of tested } \\
\text { impressions }\end{array}$} & \multicolumn{2}{|c|}{ LENTULO } & \multicolumn{2}{c|}{ NEEDLE } & \multicolumn{2}{c|}{ PISTOL } \\
\cline { 2 - 7 } & $\begin{array}{c}\text { impressions } \\
\text { number }\end{array}$ & $\begin{array}{c}\text { impressions } \\
\text { ratio }\end{array}$ & $\begin{array}{c}\text { impressions } \\
\text { number }\end{array}$ & $\begin{array}{c}\text { impressions } \\
\text { ratio }\end{array}$ & $\begin{array}{c}\text { impressions } \\
\text { ratio }\end{array}$ & $\begin{array}{c}\text { impressions } \\
\text { number }\end{array}$ \\
\hline $\begin{array}{l}\text { Successful } \\
\text { impressions }\end{array}$ & 14 & $\mathbf{5 0 . 0 \%}$ & 8 & $28.6 \%$ & 5 & $17.6 \%$ \\
\hline $\begin{array}{l}\text { Unsuccesssful } \\
\text { impressions }\end{array}$ & 14 & $50.0 \%$ & 20 & $71.4 \%$ & 23 & $82.4 \%$ \\
\hline \hline
\end{tabular}

Ta b 1 e 5. Average on the three-point scale (1 - clinically unacceptable impression, 2 - clinically acceptable impression, 3 - ideal impression) for impressions taken in the single-canal teeth in three groups according to the impression method (LENTULO, NEEDLE, PISTOL)

\begin{tabular}{|l|c|c|c|c|}
\hline & LENTULO & NEEDLE & PISTOL & P-value \\
\hline Range (min-max) & $1-3$ & $1-3$ & $1-3$ & \multirow{2}{*}{0.0559} \\
\hline Median & 3.0 & 3.0 & 3.0 & \\
\hline
\end{tabular}

compared with the PISTOL group $(\mathrm{p}=0.0227)$ (Tab. 4).

In the group of impressions taken with the PISTOL method, $21.2 \%$ of the impressions were assessed as clinically unacceptable, which necessitated the repetition of the entire procedure. In the same group, $17.3 \%$ impressions were not perfect but clinically acceptable for the further procedure despite minor imperfection, while $61.5 \%$ of the impressions were deemed perfect. In the group of impressions taken with the LENTULO method, there were $7.7 \%$ of impressions clinically unacceptable, $15.4 \%$ impressions with minor deficiencies, and $76.9 \%$ of perfect impressions. The group of impressions taken with the NEEDLE method showed $25.0 \%$ of the clinically unacceptable impressions, $17.3 \%$ of imperfect but acceptable impressions and $57.7 \%$ of perfect impressions. Evaluation of the impression taken with different methods in the single-canal teeth did not show statistically significant differences ( $p$ $=0.1642)$ (Tab. 5).
- wyniki uzyskane w grupie zębów wielokanałowych:

W grupie wycisków pobieranych w zębach wielokanałowych metodą PISTOLET było $17,6 \%$ wycisków poprawnych i $82,4 \%$ wycisków niepoprawnych. W grupie wycisków pobieranych metodą LENTULO było 50,0\% wycisków poprawnych i 50,0\% wycisków niepoprawnych, podczas gdy w grupie wycisków pobieranych metodą IGŁA było 28,6\% wycisków poprawnych i 71,4\% wycisków niepoprawnych. W grupie LENTULO było istotnie więcej wycisków poprawnych w porównaniu do grupy PISTOLET ( $\mathrm{p}=0,0227)$ (tab. 4).

W grupie wycisków pobieranych metodą PISTOLET 21,2\% wycisków oceniono jako wyciski nieakceptowalne klinicznie, co oznaczało konieczność powtórzenia wycisku. Odsetek 17,3\% uzyskano dla wycisków niedokładnych, a więc możliwych do zaakceptowania pomimo drobnych niedokładności. 61,5\% wycisków zakwalifikowano jako idealne. W grupie wycisków pobieranych metodą 
Ta b le 6. Number and ratio (\%) of impressions evaluated on the three-point scale in single-canal teeth in three groups (depending on the impression method), LENTULO, NEEDLE, PISTOL. Underlined was the method in which the most clinically beneficial result was obtained

\begin{tabular}{|l|c|c|c|c|c|c|}
\hline \multirow{2}{*}{$\begin{array}{c}\text { Number } \\
\text { of tested } \\
\text { impressions } 78\end{array}$} & \multicolumn{2}{|c|}{ LENTULO } & \multicolumn{2}{c|}{ NEEDLE } & \multicolumn{2}{c|}{ PISTOL } \\
\cline { 2 - 7 } & $\begin{array}{c}\text { impressions } \\
\text { number }\end{array}$ & $\begin{array}{c}\text { impressions } \\
\text { ratio }\end{array}$ & $\begin{array}{c}\text { impressions } \\
\text { number }\end{array}$ & $\begin{array}{c}\text { impressions } \\
\text { ratio }\end{array}$ & $\begin{array}{c}\text { impressions } \\
\text { ratio }\end{array}$ & $\begin{array}{c}\text { impressions } \\
\text { number }\end{array}$ \\
\hline $\begin{array}{l}\text { Clinically } \\
\text { unacceptable } \\
\text { impressions }\end{array}$ & 4 & $7.7 \%$ & 13 & $25.0 \%$ & 11 & $21.2 \%$ \\
\hline $\begin{array}{l}\text { Imperfect } \\
\text { impressions }\end{array}$ & 8 & $15.4 \%$ & 9 & $17.3 \%$ & 9 & $17.3 \%$ \\
\hline $\begin{array}{l}\text { Ideal } \\
\text { impressions }\end{array}$ & 40 & $\mathbf{7 6 . 9 \%}$ & 30 & $57.7 \%$ & 32 & $61.5 \%$ \\
\hline $\begin{array}{l}\text { Clinically } \\
\text { acceptable } \\
\text { impressions }\end{array}$ & 48 & $\mathbf{9 2 . 3 \%}$ & 39 & $75.0 \%$ & 41 & $78.8 \%$ \\
\hline
\end{tabular}

With the total assessment of the imperfect but acceptable and perfect impressions, the results showed that in the group of impressions taken with the PISTOL method $78.8 \%$ of the impressions were classified as acceptable and suitable for the clinical use, while in the "LENTULO" group such impressions accounted for $92.3 \%$. The lowest percentage, although not statistically significant, was recorded in the NEEDLE method group of impressions (75.0\%) (Tab. 6).

The median of impressions in the PISTOL group was 2.0, in the LENTULO group 3.0 and in the NEEDLE group 2.17. The impressions in the LENTULO group were statistically significantly better compared to the PISTOL group (post-hoc: $p=0.003$ ) (Tab. 7).

The median of the impression taken in the lower molars in the PISTOL group was 2.0, in the LENTULO group 2.42, and in the NEEDLE group 2.17 . There were statistically significant differences between groups $(p=0.0375)$. The median of the impression taken in the upper molars in the PISTOL group was 2.0, in the LENTULO group 2.5, and in the NEEDLE group 2.17. The impressions in the LENTULO
LENTULO było 7,7\% wycisków nieakceptowalnych klinicznie, 15,4\% stanowiły wyciski z drobnymi uchybieniami, a 76,9\% wycisków było idealnych. W grupie wycisków pobieranych metodą IGŁA było 25,0\% wycisków nieakceptowalnych klinicznie, 17,3\% wycisków „niedokładnych” oraz 57,7\% wycisków idealnych. Ocena metod pobrania wycisku w zębach jednokanałowych nie wykazała statystycznie istotnych różnic $(\mathrm{p}=0,1642)$ (tab. 5).

Przy łącznej ocenie wycisków niedokładnych i idealnych (jako możliwych do wykorzystania w warunkach klinicznych) wyniki wykazały, że w grupie wycisków pobieranych metodą PISTOLET było 78,8\% wycisków zakwalifikowano jako akceptowalne i możliwe do klinicznego wykorzystania, podczas gdy w grupie „LENTULO” takich wycisków było 92,3\%. Najniższy odsetek, aczkolwiek nie różniący się istotnie statystycznie odnotowano w grupie wycisków pobieranych metodą IGŁA (75,0\%) (tab. 6).

Mediana punktacji wycisków w grupie PISTOLET wyniosła 2,0, w grupie LENTULO 3,0 oraz w grupie IGŁA 2,17. Statystycznie istotnie wyżej oceniono wyciski $\mathrm{w}$ grupie 
Ta b 1 e 7 . Average on the three-point scale ( 1 - clinically unacceptable impression, 2 - clinically acceptable impression, 3 - ideal impression) for impressions taken in the single-canal teeth in three groups depending on the impression method (LENTULO, NEEDLE, PISTOL)

\begin{tabular}{|l|c|c|c|c|}
\hline & LENTULO & NEEDLE & PISTOL & P-value \\
\hline Range (min-max) & $1-3$ & $1-3$ & $1-3$ & \multirow{2}{*}{0.0025} \\
\hline Median & 3.0 & 2.17 & 2.0 & \\
\hline
\end{tabular}

Ta b 1 e 8 . Average on the three-point scale (1 - clinically unacceptable impression, 2 - clinically acceptable impression, 3 - ideal impression) for impressions taken in the multi-canal teeth in three groups depending on the impression method (LENTULO, NEEDLE, PISTOL)

\begin{tabular}{||c|c|c|c|c|}
\hline \multicolumn{1}{|c|}{ Lower molar } & LENTULO & NEEDLE & PISTOL & P-value \\
\hline Range (min-max) & $1-3$ & $1-3$ & $1-3$ & \multirow{2}{*}{0.0375} \\
\hline Median & $\mathbf{2 . 4 2}$ & 2.17 & 2.0 & \multirow{2}{*}{ P-value } \\
\hline Upper Molar & LENTULO & NEEDLE & PISTOL & \multirow{2}{*}{0,0470} \\
\hline Range (min-max) & $\mathbf{1 - 3}$ & $1-3$ & $1-3$ & \\
\hline Median & $\mathbf{2 . 5}$ & 2.17 & 2.0 & \\
\hline
\end{tabular}

group were significantly better compared to the PISTOL group $(\mathrm{p}=0.0472)$ (Tab. 8).

\section{Discussion}

The dental root acts as a natural implant and its correct utilization allows postponing an implantation procedure or grinding adjacent abutment teeth to deliver a prosthetic bridge in the case of tooth loss. The prerequisite for the proper functioning of the post is an appropriate preparation of the root canal followed by taking an impression that precisely reproduces the inner part of the root canal. Consequently, the impression method should be predictable, repeatable and uncomplicated. In the worldwide literature, there is insufficient general data concerning the impression methods used to replicate the inside of the root canal, ${ }^{4,11-13}$ while the accuracy of the impression, and thus the tight adherence of the individual post to the canal walls is the critical condition for maintaing
LENTULO, w porównaniu do grupy PISTOLET (post-hoc: $\mathrm{p}=0$,003) (tab. 7).

Mediana punktacji wycisków pobieranych w zębach trzonowych dolnych w grupie PISTOLET wyniosła 2, 0, w grupie LENTULO 2,42, a w grupie IGŁA2,17. Stwierdzono różnice istotne statystycznie w punktacjach wycisków pomiędzy grupami $(\mathrm{p}=0,0375)$. Analiza post-hoc nie wykazała istotnych różnic. Mediana punktacji wycisków pobieranych w zębach trzonowych górnych w grupie PISTOLET wyniosła 2,0, w grupie LENTULO 2,5, a w grupie IGŁA 2,17. Istotnie statystycznie lepiej oceniono wyciski w grupie LENTULO, w porównaniu z grupą PISTOLET ( $p=0,0472)$ (tab. 8).

\section{Dyskusja}

Korzeń zęba stanowi naturalny implant, a jego prawidłowe wykorzystanie pozwala odroczyć postępowanie implantacyjne lub szlifowanie sąsiednich zębów filarowych celem 
the strength of the root, and thus expect a long-term survival of a prosthetic restoration in the oral cavity. The method of transfer of the chewing forces through a customized, metal post is comparable to the stress generated in the teeth rebuilt without the use of post and core. In consequence, we gain an increased tooth resistance to fracture and better marginal integrity of the prosthetic crown. ${ }^{5}$ However, proper impression of the canal system is a prerequisite for the correct interaction of the future post with the root walls.

In the current study, we analysed the impressions taken with three methods in conditions that mimic those in the oral cavity. The LENTULO method proved to be the best one to achieve the precise impressions in both the single- and multi-rooted teeth. The exception were the impressions taken in the lower molars, where the NEEDLE method proved to be the most beneficial one. The results of the computer analysis were mostly consistent with those obtained from the clinical analysis; However, the method of clinical evaluation showed to be less restrictive because it indicated an acceptance for a further procedure of more impressions compared to the results from the computer evaluation. However, despite the slight discrepancies in the personal assessments between the two researchers, the Lentulo method was still indicated as the most accurate and predictable one. It is noteworthy that the results described in the present experiment are contradictory to those obtained by Chee et al., ${ }^{6}$ who claimed that using the Lentulo method, they obtained nearly $80 \%$ of failures, whereas using the injection needle as a vent allowed obtaining $100 \%$ of successful impressions. However, the authors did not explain the methodology of Lentulo needle usage when applying an impression material. An additional critical factor might be the fact that Chee et al. applied an impression material into the root canals of acrylic teeth. wykorzystania ich jako filarów do wykonania mostu protetycznego w przypadku utraty zęba. Warunkiem prawidłowego funkcjonowania wkładu koronowo-korzeniowego jest oprócz dokładnego opracowania kanału korzeniowego, wykonanie wycisku, który wiernie odwzorowuje wnętrze kanału korzeniowego. W związku z powyższym metoda wyciskowa powinna być przewidywalna, powtarzalna i nieskomplikowana. W piśmiennictwie istnieją nieliczne ogólne informację dotyczące metod wyciskowych stosowanych do odwzorowania wnętrza kanału korzeniowego, ${ }^{4,11-13}$ podczas gdy dokładność wykonanego wycisku, a tym samym szczelne przyleganie indywidualnego wkładu koronowo-korzeniowego do ścian kanału jest warunkiem kluczowym dla wytrzymałości korzenia zęba, a co za tym idzie długoterminowego przetrwania uzupełnienia protetycznego w jamie ustnej. Sposób przenoszenia sił żucia poprzez indywidualny, metalowy wkład koronowo-korzeniowy jest porównywalny do przenoszenia $\mathrm{w}$ głąb korzenia naprężeń powstających w zębach odbudowanych bez użycia wkładu. W konsekwencji zyskuje się mniejszą podatność zęba na złamanie i lepszą integrację brzeżną korony protetycznej. ${ }^{5}$ Jednak warunkiem wykonania prawidłowego wkładu $\mathrm{k}-\mathrm{k}$ jest pobranie precyzyjnego wnętrza kanału korzeniowego.

W doświadczeniu będącym przedmiotem pracy, analizie poddano trzy metody wyciskowe w warunkach zbliżonych do panujących w jamie ustnej. Metodą pozwalającą uzyskać najbardziej precyzyjne wyciski zarówno w zębach jedno- jak i wielokorzeniowych okazała się metoda LENTULO. Wyjątek stanowiły wyciski pobierane w zębach trzonowych dolnych, gdzie najkorzystniejsza okazała się metoda IGŁA. Wyniki analizy komputerowej w większości były zgodne z wynikami uzyskanymi z analizy klinicznej, jednak metoda oceny klinicznej okazała się bardziej „łagodna" gdyż wskazywała na zaakceptowanie do 
This significantly changes the conditions of the experiment compared to those described in the current study.

The observations made during the current experiment allow us to state categorically that impression material application in the root canal is a critical factor to obtain the precise reproduction of the prosthetic model. It directly affects the quality of the prosthetic reconstruction, and thus the time of survival of both the abutment tooth and prosthetic restoration in the oral cavity. The results of the study showed that the LENTULO method guarantees achievement of the most precise impressions characterized by such parameters like the largest amount of material introduced into the canals with maintaining its continuity, lack of raggedness or tears and closed air bubbles. These observations allow recommending the LENTULO method as the one that ensures precise impressions for posts both in the single and multi-canal teeth. dalszego postępowania leczniczego większej liczby wycisków w porównaniu do oceny cyfrowej. Jednak, pomimo nieznacznych rozbieżności w ocenie, w znaczącej przewadze metoda LENTULO została wskazana jako najbardziej dokładna i przewidywalna. Ciekawym pozostaje fakt, iż wyniki opisane w doświadczeniu pozostają w sprzeczności z pozyskanymi przez Chee i wsp. ${ }^{6}$ Wspomniani autorzy wykazali, że wykorzystując metodę z zastosowaniem igły Lentulo uzyskali blisko $80 \%$ odsetek niepowodzeń, podczas gdy zastosowanie igły iniekcyjnej jako wentyla odpowietrzającego pozwoliło uzyskać $100 \%$ wycisków udanych. Autorzy jednak nie wyjaśniają metodologii użycia igły Lentulo przy aplikacji masy wyciskowej. Dodatkowym czynnikiem krytycznym może być również fakt, że Chee i wsp. aplikowali masę wyciskową do kanałów korzeniowych zębów wykonanych z tworzywa sztucznego, co znacząco zmienia warunki doświadczenia w stosunku do opisywanych w pracy.

Obserwacje dokonane podczas obecnego doświadczenia pozwalają jednoznacznie stwierdzić, że aplikacja masy do kanału korzeniowego jest momentem krytycznym dla uzyskania prawidłowego odwzorowania podłoża protetycznego. Bezpośrednio wpływa ona na jakość wykonanej odbudowy protetycznej, a co za tym idzie czas przetrwania zęba filarowego wraz $\mathrm{z}$ nadbudową protetyczną $\mathrm{w}$ jamie ustnej. Metoda LENTULO gwarantuje uzyskanie wycisków precyzyjnych charakteryzujących się takimi parametrami oceny jak największa ilość masy wprowadzonej do kanałów z zachowaniem ciągłości masy, brak poszarpania, zerwania masy oraz zamkniętych pęcherzy powietrza. Poczynione obserwacje pozwalają rekomendować metodę LENTULO do wykonywania precyzyjnych wycisków pod wkłady koronowo-korzeniowe zarówno w zębach jednojak i wielokanałowych. 


\section{References / Piśmiennictwo}

1. Pryliński M, Majewski SW: Rekonstrukcja protetyczna zębów po leczeniu endodontycznym. Wydawnictwo Elamed; 2013.

2. Spiechowicz E: Protetyka stomatologiczna. Wydawnictwo Lekarskie PZWL; 2010.

3. Morgano SM, Brackett SE: Foundation restorations in fixed prosthodontics: current knowledge and future needs. J Prosthet Dent Elsevier 1999; 82(6): 643-657.

4. Żarow M, D'Anrcangelo C, Felippe LA,Paniz $G$, Paolone $G$ : Endoprotetyka przewodnik dla praktyki. Wydawnictwo Kwintesencja Warszawa; 2013.

5. Dejak B, Suchorzewski A: Porównanie właściwości zębów odbudowanych wkładami koronowo-korzeniowymi lanymi i standardowymi kompozytowymi wzmacnianymi włóknami szklanymi na podstawie piśmiennictwa. Protet Stomatol 2010; LX(1): 37-43.

6. Fokkinga WA, Kreulen CM, Bronkhorst EM, Creugers NHJ: Up to 17-year controlled clinical study on post-and-cores and covering crowns. J Dent [Internet]. 2007 Oct [cited 2018 Oct 1]; 35(10): 778-786. Available from: http://www.ncbi.nlm.nih.gov/pubmed/ 17716800

7. Stanio J, Klimuszko E, Gołębiewska M: Odbudowa zębów leczonych endodontycznie - wkłady indywidualne czy standardowe? Mag Stomatol 2012; (12): 12-15.
8. Soares CJ, Valdivia ADCM, da Silva GR, Santana FR, Menezes $M$ de $S$ : Longitudinal clinical evaluation of post systems: a literature review. Braz Dent J [Internet]. 2012 [cited 2018 Oct 1];23(2):135-740. Available from: http://www.ncbi.nlm.nih.gov/pubmed/ 22666771

9. Rosenstiel SF, Land MF, Fujimoto J, Dobies $K$, Tomankiewicz M: Współczesne protezy stałe. Wydaw Czelej; 2002.

10. Dejak B: Kompendium wykonywania uzupełnień protetycznych. Wydawnictwo Med Tour Press International; 2014.

11. Napadtek P, Panek $H$ : Rehabilitacja protetyczna u pacjentów z jednostronnie skróconym łukiem zębowym. Dent Med Probl 2006; 43(2): 293-298.

12. Chatzopoulos GS, Koidou VP, Lunos S, Wolff $L F$ : Implant and root canal treatment: survival rates and factors associated with treatment outcome. Journal of Dentistry. Elsevier 2018; 71: 61-66.

13. Moshaverinia A, Kar K, Chee WWL: Treatment planning decisions: implant placement versus preserving natural teeth. CDA Journal 2014; 42(12): 859-868.

Zaakceptowano do druku: 06.06.2019 r.

Adres autorów: 80-208 Gdańsk, ul. Orzeszkowej 18.

(C) Zarząd Główny PTS 2019. 